\title{
A new agent for flap survival - Hippophae rhamnoides L. (sea buckthorn): An experimental study in rats
}

\author{
Ilteris Murat Emsen MD
}

\author{
IM Emsen. A new agent for flap survival - Hippophae \\ rhamnoides L. (sea buckthorn): An experimental study in rats. \\ Can J Plast Surg 2005;13(4):195-198.
}

\begin{abstract}
Hippophae rhamnoides L. (sea buckthorn) is a member of the Elaeagnaceae family, and is a temperate bush native to Europe and Asia. The antioxidant activity of $\mathrm{H}$ rhamnoides L. has been shown in vitro cell culture and animal studies. Different fractions of $\mathrm{H}$ rhamnoides $\mathrm{L}$. fruits inhibit 2,2-azobis-(2,4 dimethylvaleronitrile) and ascorbate iron-induced lipid peroxidations in vitro. $H$ rhamnoides L., as well as vitamin E, decrease the malondialdehyde content in hyperlipidemic rabbit serum-cultured smooth muscle cells. The aim of the present study was to investigate, in a rat model, the potential effect of $H$ rhamnoides $L$. on survival of random pattern skin flaps. For this purpose, 30 Wistar Albino rats were used, and a McFarlane-type caudally based skin flap was created on the dorsum of the rat $(2.5 \mathrm{~cm} \times 8 \mathrm{~cm})$. Rats were divided into three groups: one control (group A) and two treatment groups (groups B and C). H rhamnoides L. was administered orally to the experimental groups: group B received a single $15 \mathrm{mg} / \mathrm{kg}$ dose per day and group $\mathrm{C}$ received $15 \mathrm{mg} / \mathrm{kg}$ twice per day. The areas and lengths of flap necrosis were measured in each group. The extent of necrotic flap areas were evaluated as length and area of total flap area, and differences were studied by Student's $t$ tests. The areas and lengths of necrosis of skin flaps decreased depending on H rhamnoides L., but viability of the flaps treated with $15 \mathrm{mg} / \mathrm{kg} / \mathrm{day}$ was not significantly different from the control group. The rats receiving $H$ rhamnoides $\mathrm{L} .15 \mathrm{mg} / \mathrm{kg}$ twice per day had the highest flap survival rate $(\mathrm{P}<0.001)$. In conclusion, $H$ rhamnoides $\mathrm{L}$. may have a dose-dependent effect to increase flap survival in random skin flaps.
\end{abstract}

Key Words: Antioxidant activity; Flap survival; Hippophae rhamnoides L. (sea buckthorn); Skin flaps

\section{Un nouvel agent, l'Hippophae rhamnoides L., pour la survie du lambeau (argousier) : Une étude expérimentale chez les rats}

\begin{abstract}
L'Hippophae rhamnoides L. (argousier) fait partie de la famille des élaégnacées. C'est un arbrisseau des régions tempérées d'Europe et d'Asie. L'activité anti-oxydante de l'H rhamnoides L. est démontrée dans des cultures cellulaires in vitro et des études auprès d'animaux. Différentes fractions des fruits de l'H rhamnoides L. inhibent le 2,2-azobis(2,4 diméthylvaléronitrile) et les péroxydations lipidiennes induites par l'ascorbate de fer in vitro. À l'instar de la vitamine E, l'H rhamnoides $\mathrm{L}$. réduit le contenu malonaldéhyde des cellules des muscles mous de lapins lipémiants cultivées dans un sérum. La présente étude visait à explorer, dans un modèle murin, l'effet potentiel de l'H rhamnoides L. sur la survie de lambeaux cutanés à motifs aléatoires. À cet effet, 30 rats albinos Wistar ont été utilisés, et un lambeau cutané caudal de type McFarlane a été créé sur le dos des rats $(2,5 \mathrm{~cm} \times 8 \mathrm{~cm})$. Les rats ont été divisés en trois groupes un groupe témoin (groupe A) et deux groupes traités (groupes B et C). De l'H rhamnoides L. a été administré par voie orale aux groupes expérimentaux : le groupe B a reçu une seule dose de $15 \mathrm{mg} / \mathrm{kg}$ par jour et le groupe $\mathrm{C}, 15 \mathrm{mg} / \mathrm{kg}$ deux fois par jour. Les zones et la longueur de la nécrose des lambeaux étaient mesurées dans chaque groupe. L'importance des zones nécrotiques des lambeaux a été évaluée selon la longueur et la zone de l'ensemble du lambeau, et les différences ont été étudiées à l'aide de tests de Student. La zone et la longueur de la nécrose des lambeaux cutanés diminuaient selon l'H rhamnoides L., mais la viabilité des lambeaux traités par $15 \mathrm{mg} / \mathrm{kg} /$ jour n'était pas significativement différente de celle du groupe témoin. Les rats qui prenaient $15 \mathrm{mg} / \mathrm{kg}$ d'H rhamnoides L. deux fois par jour présentaient le taux de survie des lambeaux le plus élevé $(\mathrm{P}<0,001)$. Pour conclure, l'H rhamnoides L. pourrait avoir un effet proportionnel à la dose pour accroître la survie de lambeaux cutanés aléatoires.
\end{abstract}

Since the 1950s, many medicinal preparations of Hippophae Srhamnoides L. (sea buckthorn), from both wild and cultivated sources, have been clinically used to treat radiation damage, burns, oral inflammation and gastric ulcers in China and Former Soviet Republics $(1,2)$. Previously, H rhamnoides L. has been studied on the basis of its nutrient content. There is little information available about the relationship between antioxidant effect and the different active compounds in the berries of $H$ rhamnoides L. Antioxidant activity of $H$ rhamnoides L. has been shown in in vitro cell culture and animal studies. Different fractions of $\mathrm{H}$ rhamnoides L. fruits inhibit 2,2-azobis(2,4 dimethylvaleronitrile) which carries out oxidation via lipid soluble peroxyl radical generating systems and ascorbate iron-induced lipid peroxidations in vitro. $\mathrm{H}$ rhamnoides L., as well as vitamin $\mathrm{E}$, decreases the malondialdehyde (MDA) (which is an indicator of lipid peroxidation, and causes oxidative damage) content in hyperlipidemic rabbit serum-cultured smooth muscle cells (3-5). The phenolic composition of juice derived from fruits of $\mathrm{H}$ rhamnoides $\mathrm{L}$. was investigated by highperformance liquid chromatography with diode array and electrochemical detection (6). Flavonols were found to be the predominating polyphenols, while phenolic acids and catechins represent minor components (7-9). Phenolic compounds such as quercetin 3-O-glycosides, catechins and hydroxybenzoic acids with a catechol structure exhibited good antioxidant capacities, but their concentration in $H$ rhamnoides L. juice was 


\begin{tabular}{|c|c|c|c|}
\hline Rat & $\begin{array}{c}\text { Group A } \\
\text { Length of } \\
\text { necrosis }(\mathbf{m m})\end{array}$ & $\begin{array}{c}\text { Group B } \\
\text { Length of } \\
\text { necrosis }(\mathrm{mm})\end{array}$ & $\begin{array}{c}\text { Group C } \\
\text { Length of } \\
\text { necrosis }(\mathrm{mm})\end{array}$ \\
\hline 1 & 52 & 42 & 12 \\
\hline 2 & 42 & 26 & 14 \\
\hline 3 & 41 & 34 & 10 \\
\hline 4 & 31 & 27 & 16 \\
\hline 5 & 75 & 40 & 15 \\
\hline 6 & 45 & 33 & 11 \\
\hline 7 & 44 & 21 & 17 \\
\hline 8 & 41 & 22 & 11 \\
\hline 9 & 46 & 28 & 10 \\
\hline 10 & 42 & 23 & 11 \\
\hline Mean & 45.9 & 29.6 & 13.2 \\
\hline
\end{tabular}

small, accounting for less than $5 \%$ of the total antioxidant activity of the filtered juice. Ascorbic acid was shown to be the major antioxidant in $\mathrm{H}$ rhamnoides L. juice. Because of its high concentration $(1.22 \mathrm{~g} / \mathrm{L})$, ascorbic acid contributes approximately $75 \%$ to the total $H$ rhamnoides L. antioxidant activity (10-12).

Random pattern skin flaps have multiple arteries that originate from muscle and subcutaneous fat tissue, covered by skin. In every flap elevation, distal flap necrosis inevitably occurs. Distal flap necrosis may, at worst, result in postoperative mortality, but patient aesthetics and costs are also of concern. There are a number of methods designed to improve flap survival, but the factors that result in flap ischemia are difficult to determine. This, in addition to the variety of flap types, makes it difficult to determine why certain agents are effective in promoting flap survival.

Ideally, agents that promote flap survival should also be cost-effective. There are a large number of anti-ischemic agents available; some are prohibitively expensive, difficult to obtain or have not yet been researched in experimental animal models. Because of the ongoing controversy regarding the use of $H$ rhamnoides L. for flap survival, we investigated its effects on the survival of random pattern skin flaps in an experimental rat model.

\section{MATERIALS AND METHODS}

The Institutional Animal Care and Use Committee at the Ministry of Health, Ataturk University Medical Faculty, Department of Plastic and Reconstructive Surgery, Erzurum, Turkey, approved this study.

\section{Experimental protocol}

Thirty male Wistar Albino rats weighing $260 \mathrm{~g}$ to $300 \mathrm{~g}$ were used in this study. Animals were housed in separate rat cages at $22^{\circ} \mathrm{C}$ and were fed with rodent food and tap water ad libitum. Animals were anesthetised with an intraperitoneal injection of a combination of ketamine $(100 \mathrm{mg} / \mathrm{mL})$ and xylazine $(20 \mathrm{mg} / \mathrm{mL})$ at a total dose of $0.2 \mathrm{~mL} / 100 \mathrm{~g}$ of body weight. Dorsal hair was removed with an electric shaver, and all surgical procedures were performed under sterile conditions. A McFarlane-type caudally based skin flap was created on the dorsum of the rat $(2.5 \mathrm{~cm} \times 8 \mathrm{~cm})$, using the iliac crest as a constant anatomical landmark to ensure positioning. The flap was elevated beneath the panniculus carnosus (which is equivalent to the subcutaneous fat in humans), and each flap was immediately sutured back to its donor site with continuous $4 / 0$ silk sutures. When perforating vessels were found in the base of flaps, they were electrically cauterized to make flaps with a completely random vascular pattern.

\section{Administration of $\mathrm{H}$ rhamnoides $\mathrm{L}$.}

H rhamnoides L. capsules (83 g) (Biomega-7, Hankintatukku Oy, Finland) were obtained from commercially available sources and dissolved with tap water to obtain a homogenous drug solution. Biomega $30 \mathrm{mg}$ was diluted with $30 \mathrm{mg}$ normal tap water in Chemistry Laboratories. Thus, $30 \mathrm{mg}$ Biomega was decreased to $15 \mathrm{mg}$, which was used in the experiment. The first drug solution was administered to the animals $3 \mathrm{~h}$ after the surgical procedure, using a mouth gag and feeding tube. Animals were divided in three groups. Group A $(n=10)$ was the control group and received only tap water during the experiment. Group B $(\mathrm{n}=10)$ received one $15 \mathrm{mg} / \mathrm{kg}$ dose of $H$ rhamnoides $L$ per day for seven days, and group C $(n=10)$ received $15 \mathrm{mg} / \mathrm{kg}$ twice a day for seven days (total $30 \mathrm{mg} /$ day). In total, group B received $61.6 \mathrm{mg} \mathrm{H}$ rhamnoides L. with $75.64 \mathrm{~mL}$ buffer solution (resolving tap water solution) during the treatment procedure, and group $C$ received $162.63 \mathrm{mg}$ $H$ rhamnoides L. with $70.8 \mathrm{~mL}$ buffer solution. The flaps were photographed and observed over the seven days. At the end of the seven-day experimental period, the survival lengths of flaps was measured using a planimeter, which is a specific and simple millimetric measurement tool for macroscopic evaluation.

\section{Statistical method}

Study results were evaluated with Student's $t$ test.

\section{RESULTS}

No animal died from the drug treatment or the surgical procedure. All experimental flaps exhibited sharp demarcations between viable and necrotic areas that were easily measured by planimeter (Table 1). The average length of flap necrosis in group A (control group) was $45.9 \mathrm{~mm}$ (Figure 1). The average length of flap necrosis in group B (treated with $15 \mathrm{mg} / \mathrm{kg} /$ day extract of $H$ rhamnoides L.) was $29.6 \mathrm{~mm}$ ( $\mathrm{P}<0.001$ compared with group A), while group $\mathrm{C}$ (treated with a total of $30 \mathrm{mg} / \mathrm{kg} /$ day extract of $\mathrm{H}$ rhamnoides L.) had an average necrotic length of $13.2 \mathrm{~mm}(\mathrm{P}<0.001$ compared with group $\mathrm{B})$. There was a statistically significant difference in survival rates between groups A and B and between groups A and C (using Student's $t$ test). The highest flap survival rate was in group C, which received two $15 \mathrm{mg} / \mathrm{kg}$ doses per day of $\mathrm{H}$ rhamnoides $\mathrm{L}$. (Figure 2). Therefore, the length of necrotic areas in random skin flaps decreased with higher doses of $\mathrm{H}$ rhamnoides $\mathrm{L}$.

\section{DISCUSSION}

At present, the pathogenesis of ischemia in the acute skin flap is unclear. The current thinking is that vasospasm is the main cause of ischemic necrosis of the skin flap. Recent studies have suggested that increased neutrophil adhesiveness has an important role in tissue injury involving the ischemic 'at-risk area of random flaps', and that inhibition of leukocyte adherence improves the distal survival of random flaps. The Student's $t$ test was used (13). Because radicals have the capacity to react 


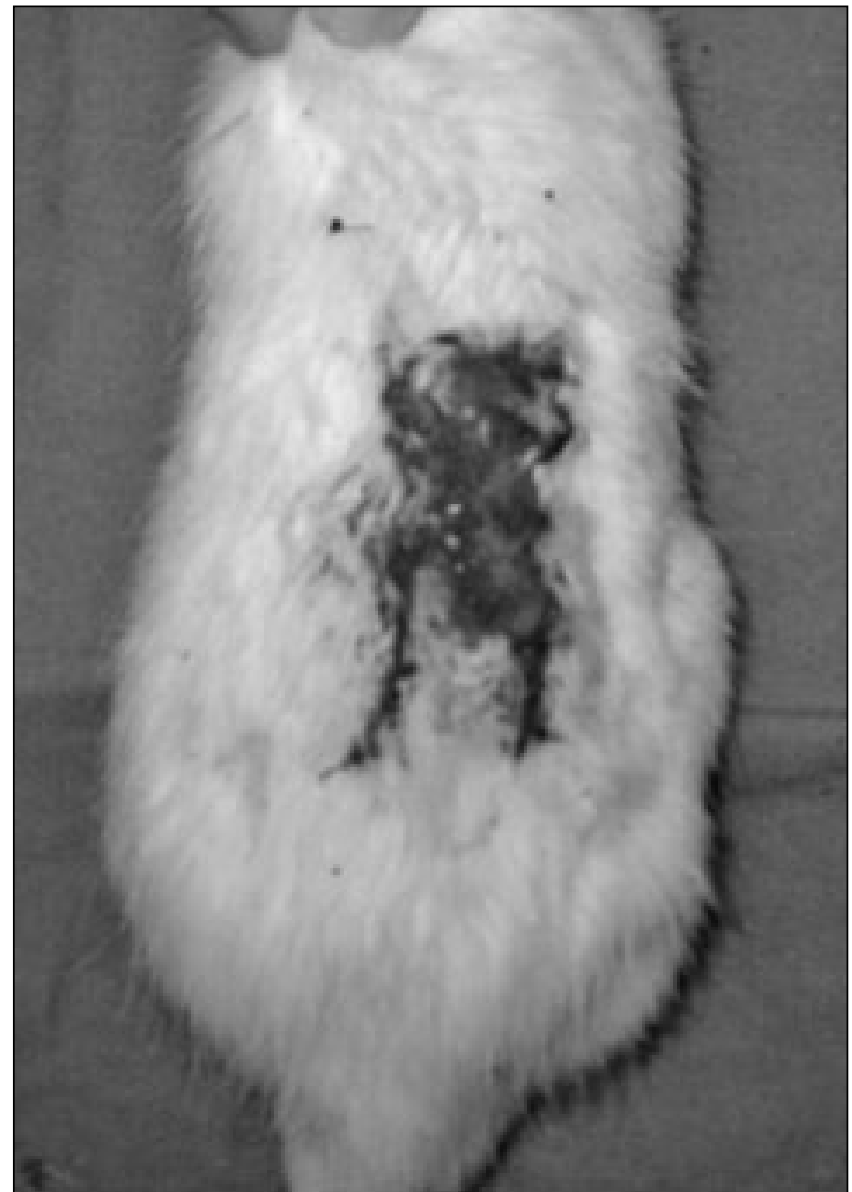

Figure 1) Necrosis of the dorsal flap is seen in the control group (Group A) seven days after the operation

in an indiscriminate manner, leading to damage to almost any cellular component, an extensive range of antioxidant defenses, both endogenous and exogenous, are present to protect cellular components from free radical-induced damage $(14,15)$. These can be divided into three main groups: antioxidant enzymes, chain-breaking antioxidants and transition metalbinding proteins (16).

\section{Lipid phase chain-breaking antioxidants}

The most important lipid phase antioxidant is probably vitamin E. The other important role of ceratin carotenoids is as precursors of vitamin A (retinol). Vitamin A also has antioxidant properties that do not, however, show any dependency on oxygen concentration. The fruits of $H$ rhamnoides L. (family Elaeagnaceae) have been well studied, and have been found to be rich in carotenoids, lipids, ascorbic acid, tocopherols, sterols and triterpenes (17-19). The oils extracted from fruit flesh or kernels have regenerating, anti-inflammatory and photoprotective effects, with promising applications in dermatology and cosmetics. The oil-bearing fruit flesh and the genotypically distinct kernels of $H$ rhamnoides $\mathrm{L}$. have interesting fatty acid compositions, being rich in 16:0 and 16:1 (9c), as well as in $18: 1(9 c, 11 c)$ and $18: 2(9 c, 12 c)$ components. Different fractions of $\mathrm{H}$ rhamnoides $\mathrm{L}$. fruits were investigated for antioxidant activity and relationships to different phytonutrients. Capacity to scavenge radicals of the crude extract, like the phenolic and ascorbate extracts, decreased significantly with increased

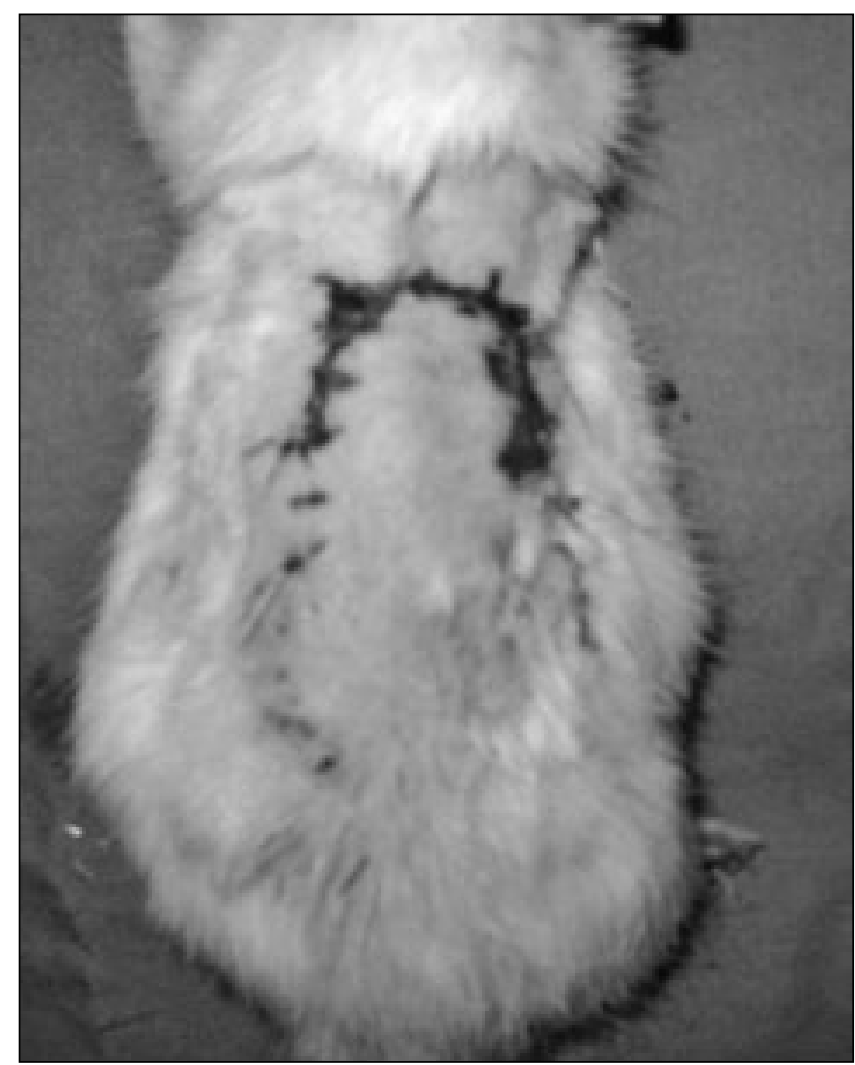

Figure 2) The effect of Hippophae rhamnoides L. on flap survival is seen seven days after the operation

maturation. The changes were strongly correlated with the content of total phenolics and ascorbic acid. Antioxidant capacity of the lipophilic extract increased significantly and corresponded to the increase in total carotenoids. The phenolic fractions made a major contribution to the total antioxidant capacity due to the high content of total phenolics. The crude extract of fruits showed the highest inhibitory effect in both 2,2-azobis-(2,4-dimethylvaleronitrile) and ascorbate-iron induced lipid peroxidations. The aqueous and ascorbatefree extracts showed higher inhibition in the 2,2-azobis(2,4-dimethylvaleronitrile) assay, but lower inhibition in ascorbate-iron-induced peroxidation, than the lipophilic extract (20-23). H rhamnoides L. supplementation also prevented the nicotine-induced decrease in erythrocyte superoxide dismutas reactivity and also remarkably increased erythrocyte glutathion peroxidase activity in nicotine-treated rats, which would have contributed to the prevention of a nicotine-induced increase in erythrocyte MDA level. It seems that alteration of antioxidant enzyme activities in response to nicotine-induced lipid peroxidation as well as the antioxidant supplementation with vitamin $\mathrm{E}$ and $\mathrm{H}$ rhamnoides L., are complicated processes (31). H rhamnoides L. has multiantioxidant products such as vitamin A, vitamin E, carotenoids, flavonoids, polyphenols, riboflavin and folic acid. These are important in salvaging some parts of necrotic distal flaps via multiple antioxidating pathways such as inhibiting 2,2-azobis(2,4 dimethylvaleronitrile), which carries out oxidation via lipid soluble peroxyl radical generating systems, and decreasing the MDA (which is an indicator of lipid peroxidation, causing oxidative damage by this way) content in hyperlipidemic rabbit serum-cultured smooth muscle cells. 


\section{CONCLUSIONS}

These findings suggest that $H$ rhamnoides $\mathrm{L}$. can contribute to survival of random pattern skin flaps in a dose-dependent way. These effects may be related to blockage of the oxidative enzymes. In addition, this extract may have a role as an enzyme coactivator against the free oxygen radicals produced in membranes and lipoprotein particles and are crucial in preventing lipid peroxidation $(24,25)$. The clinical relevance and experimental findings presented here support the idea that this agent could be used easily in every flap operation. Perhaps, it may be more effective in humans. Further clinical and experimental studies of $H$ rhamnoides L., its co-products and other plants may open new horizons on flap survival.

\section{REFERENCES}

1. Gao X, Ohlander M, Jeppsson N, Bjork L, Trajkovski V. Changes in antioxidant effects and their relationship to phytonutrients in fruits of sea buckthorn (Hippophae rhamnoides L.) during maturation. J Agric Food Chem 2000;48:1485-90.

2. Yang B, Karlsson RM, Oksman PH, Kallio HP. Phytosterols in sea buckthorn (Hippophae rhamnoides L.) berries: Identification and effects of different origins and harvesting times. J Agric Food Chem 2001;49:5620-9.

3. Pintea A, Marpeau A, Faye M, Socaciu C, Gleizes M. Polar lipid and fatty acid distribution in carotenolipoprotein complexes extracted from sea buckthorn fruits. Phytochem Anal 2001;12:293-8

4. Yang B, Kallio HP. Fatty acid composition of lipids in sea buckthorn (Hippophae rhamnoides L.) berries of different origins. J Agric Food Chem 2001;49:1939-47.

5. Suleyman H, Buyukokuroglu ME, Koruk M, et al. The effects of Hippophae rhamnoides L. extract on ethanol-induced gastric lesion and gastric tissue glutathione level in rats: A comperative study with melatonin and omeprazole. Indian J Pharmacol 2001;33:77-81.

6. Hom DB, Goding GS Jr, Price JA, Pernell KJ, Maisel RH. The effects of conjugated deferoxamine in porcine skin flaps. Head Neck 2000;22:579-84.

7. Hayden RE, Paniello RC, Yeung CS, Bello SL, Dawson SM. The effect of glutathione and vitamins $\mathrm{A}, \mathrm{C}$, and $\mathrm{E}$ on acute skin flap survival. Laryngoscope 1987;97:1176-9.

8. McGregor IA, Morgan G. Axial and random pattern flaps. Br J Plast Surg 1973;26:202-13.
9. Pang CY, Chiu C, Zhong A, Xu N. Pharmacologic intervention of skin vasospasm and ischemic necrosis in pigs. J Cardiovasc Pharmacol 1993;21:163-71.

10. Reinisch JF. The pathophysiology of skin flap circulation. The delay phenomenon. Plast Reconstr Surg 1974;54:585-98.

11. Hjortdal VE, Sinclair T, Kerrigan CL, Solymoss S. Arterial ischemia in skin flaps: Microcirculatory intravascular thrombosis. Plast Reconstr Surg 1994;93:375-85.

12. McCord JM. Oxygen-derived free radicals in postischemic tissue injury. N Engl J Med 1985;312:159-63.

13. Stewart RJ, Moore T, Bennett B, Easton M, Newton GW, Yamaguchi KT. Effect of free-radical scavengers and hyperbaric oxygen on random-pattern skin flaps. Arch Surg 1994;129:982-7.

14. Zaccaria A, Weinzweig N, Yoshitake M, Matsuda T, Cohen M. Vitamin C reduces ischemia-reperfusion injury in a rat epigastric island skin flap model. Ann Plast Surg 1994;33:620-3.

15. Halliwell B, Gutteridge JM. The definition and measurement of antioxidants in biological systems. Free Radic Biol Med 1995;18:125-6.

16. Young IS, Woodside JV. Antioxidants in health and disease. J Clin Pathol 2001;54:176-86.

17. Halliwell B, Gutteridge JC. Free Radicals in Biology and Medicine, 2nd edn. Oxford: Clarendon Press, 1989.

18. Halliwell B, Gutteridge JM. Biologically relevant metal iondependent hydroxyl radical generation. An update. FEBS Lett 1992;307:108-12.

19. Becker LB, vanden Hoek TL, Shao ZH, Li CQ, Schumacker PT. Generation of superoxide in cardiomyocytes during ischemia before reperfusion. Am J Physiol 1999;277:H2240-6.

20. Chance B, Sies H, Boveris A. Hydroperoxide metabolism in mammalian organs. Physiol Rev 1979;59:527-605.

21. Halliwell B, Gutteridge JM. Role of free radicals and catalytic metal ions in human disease: An overview. Methods Enzymol 1990;186:1-85.

22. Lloyd RV, Hanna PM, Mason RP. The origin of the hydroxyl radical oxygen in the Fenton reaction. Free Radic Biol Med 1997;22:885-8

23. Stohs SJ, Bagchi D. Oxidative mechanisms in the toxicity of metal ions. Free Radic Biol Med 1995;18:321-36.

24. Rice-Evans CA, Miller NJ, Paganga G. Structure-antioxidant activity relationships of flavonoids and phenolic acids. Free Radic Biol Med 1996;20:933-56. (Erratum in 1996;21:417.)

25. Hertog MGL, Hollman PCH, van de Putte B. Content of potentially anticarcinogenic flavonoids of tea infusions, wines and fruit juices. J Agric Food Chem 1993;41:1242-6. 